\title{
Mezofilik ve Termofilik Anaerobik Çürütmenin Çok Kriterli Karar Verme Yöntemleri ile Fayda, Maliyet ve Risk Açısından Karşılaştırılması
}

\author{
Elanur ADAR* \\ Artvin Çoruh Üniversitesi, Mühendislik Fakültesi, Çevre Mühendisliği Bölümü, Artvin \\ (ORCID: 0000-0002-9609-0439)
}

\begin{abstract}
Öz
Anaerobik çürütme atıkların stabilizasyonunu, kütle/hacim azaltımını ve aynı zamanda yenilebilir enerji üretimini sağlamaktadır. Bu çalışmanın amacı çevresel uygulama olan ve yaygın şekilde de atık/atıkların arıtımı için tam ölçekli olarak kullanılan anaerobik çürütmenin mezofilik mi yoksa termofilik şartlarda işletimi mi daha öncelikli olduğunu fayda, maliyet ve risk açısından belirlemektir. Bu yöntemlerden en etkin yöntemin seçilmesinde ele alınacak fayda, maliyet ve risk ana kriterleri için alt kriterler de belirlenerek, AHP ve TOPSİS yöntemleri ile karar verilmeye çalışılmıştır. Çalışma sonucunda her bir ana kriter açısından alternatifler değerlendirildiğinde fayda kriteri için T-AÇ, maliyet kriteri için $\mathrm{M}$-AÇ ve risk kriteri için T-AÇ’ye karar verilmiştir. Tüm kriterler beraber ele alındığında ise fayda, maliyet ve risk açısından en iyi yöntemin termofilik anaerobik çürütme olduğu söylenebilir.
\end{abstract}

Anahtar kelimeler: Anaerobik çürütme, mezofilik, termofilik, AHP, TOPSİS.

\section{Comparison of Mesophilic and Thermophilic Anaerobic Digestion with Multi-Criteria Decision Making Methods in terms of Benefit, Cost and Risk}

\begin{abstract}
Anaerobic digestion ensures the stabilization of waste/wastewaters, mass/volume reduction and at the same time producing renewable energy. The aim of this study is to determine whether anaerobic digestion, which is an environmental application and commonly used for the full-scale treatment of waste/wastewaters, has priority over mesophilic or thermophilic temperatures in terms of benefit, cost, and risk. Sub-criteria were also determined for the main criteria of benefit, cost, and risk to be considered in the selection of the most effective method and the decision was made with AHP and TOPSIS methods. At the end of the study, when the alternatives were evaluated in terms of each main criterion, it was decided to use T-AD for benefit criterion, M-AD for cost criterion and T$\mathrm{AD}$ for risk criterion. When all the criteria are considered together, it can be said that the best method in terms of benefit, cost, and risk is thermophilic anaerobic digestion.
\end{abstract}

Keywords: Anaerobic digestion, mesophilic, thermophilic, AHP, TOPSIS.

\section{Giriş}

Sanayi ve teknolojinin gelişmesi ve nüfusun artması ile her geçen gün enerjiye daha fazla ihtiyaç duyulmaktadır. Ayrıca, sanayinin gelişmesi, insan ve hayvan sayısının artması ile de arıtılması gereken farklı atık/atık suların oluşumu da artmaktadır. Hem artan enerji ihtiyacı hem de arıtılması/bertaraf edilmesi gereken atı̆̆ın artması insanoğlunu sürdürülebilir arıtım tekniklerine teşvik etmektedir. Sürdürülebilir arıtım, hem atığın kirlilik yükünü azaltmak hem de atığın içeriğinden insan ve çevre sağlığı gözetilerek faydalanılmasıdır. Anaerobik çürütme (AÇ), sürdürülebilir arıtım yöntemlerinden biridir. $\mathrm{Bu}$ yöntem, oksijen içeriğinin \%1'in altında olduğu uygun şartlar altında $(\mathrm{pH}$, sıcaklık, mikroorganizma sayıs1 ve türü, alkalinite, besin maddesi, vb.) organik içerikli atık/atık suların

*Sorumlu yazar: aelanur@artvin.edu.tr

Geliş Tarihi: 10. 10.2019, Kabul Tarihi: 08.04.2020 
ayrıştırılması işlemidir. Ayrışma sonucu bu yöntem ile organik içerik; renksiz-kokusuz, havadan hafif olan biyogaza dönüştürülmekte ve çürütme sonrası oluşan sıvı ve katı ürün ise içeriğine bağlı olarak gübre olarak değerlendirilmektedir. Oluşan biyogazın bileşimini birçok parametre etkilemektedir. Fakat substrata ve işletme şartlarına bağlı olarak yaklaşık \%40-70 metan, \%30-60 karbondioksit, \%0-3 hidrojen sülfür ile çok az miktarda azot ve hidrojen içerir [1]. Oluşan biyogaz enerjiye çevrilerek farklı amaçlar için kullanılabilir. Örneğin elektrik, 1sı veya yakıt olarak değerlendirilebilir. Sıvı ve/veya katı ürün ise ağır metaller ve patojenik mikroorganizmalar açısından uygun olduğunda gübre olarak kullanılabilir (Şekil 1). Çakır ve Stenstrom [2] yaptıkları BMP çalışmasında uygun şartlar sağlandığında oluşan metan gazının enerjiye çevrilmesi sonucunda önemli boyutlarda ekonomik kazanç sağlanabildiğini ve elde edilen enerjinin tesisin işletme maliyetini (enerji tüketimi) \%28 oranında azaltabileceğini tespit etmiştir [1]. Çeşitli atık/atıksuların stabilizasyonu ve metan gazı eldesi için kullanılan anaerobik çürütme, psikrofilik $\left(12-16{ }^{\circ} \mathrm{C}\right)$, mezofilik $\left(35-37{ }^{\circ} \mathrm{C}\right)$ ve termofilik $\left(55-60{ }^{\circ} \mathrm{C}\right)$ sıcaklıklarda gerçekleşebilmektedir. Psikrofilik ayrışma, düzenli depolamalarda, bataklıklarda ve sedimentlerde; mezofilik (M) ayrışma işkembede ve anaerobik çürütme sistemlerinde; ve termofilik (T) ayrışma ise anaerobik çürütme sistemlerinde ve jeotermal ısıtmalı ekosistemlerde gerçekleşmektedir [3]. İndirgenmiş termofilik sıcaklık $\left(47^{\circ} \mathrm{C}\right)$ Avrupa'daki beraber çürütme tesislerinde yaygın şekilde kullanılmaktadır [4]. Anaerobik çürütmede verim üzerine birçok parametre (sıcaklık, substrat bileşimi, mikroorganizma türü/sayıs1, $\mathrm{pH}$, alkalinite, besin elementleri, aktif aş1 vb.) etki etmektedir. Tek tür substrat çürütülebileceği gibi farklı substratlarda uygun oranlarda karıştırılarak beraber çürütülebilmektedir. Farklı atıkların beraber çürütülmesi daha fazla mikroorganizma popülasyonu, daha fazla nütrient dengesi, uygun $\mathrm{C} / \mathrm{N}$ oran1, toksik maddelerin seyreltilmesi yani inhibe edici etkilerin azaltılması, artan stabilizasyon ve artan metan oluşumu demektir [3].

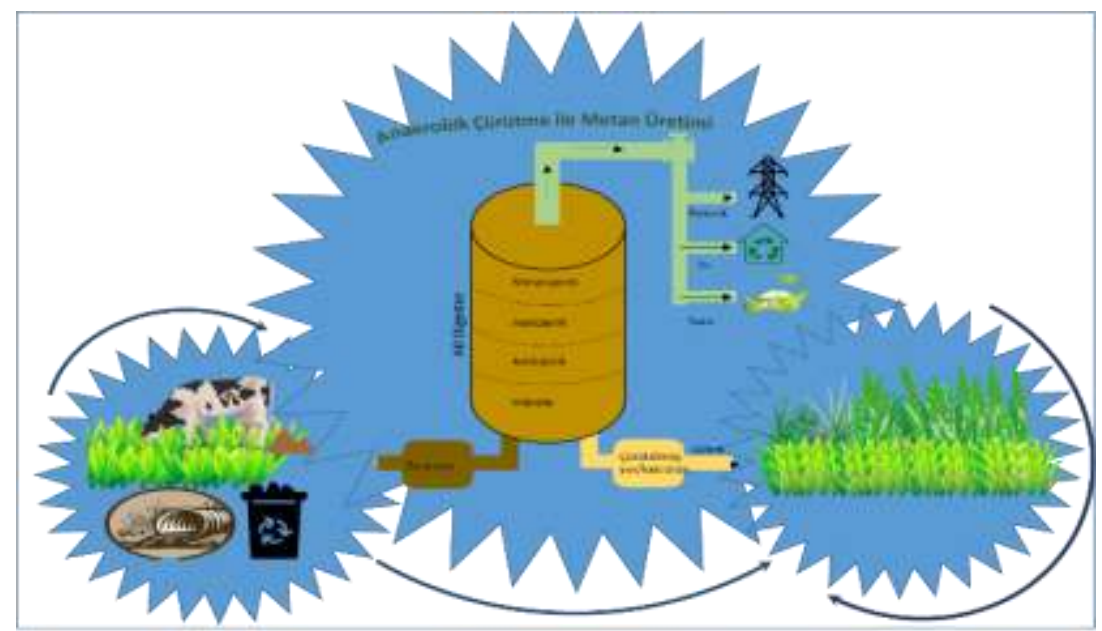

Şekil 1. Atık/atık suların anaerobik çürütülmesi ve oluşan ürünlerin kullanımı

Gerçek hayat problemlerinin en karakteristik özelliklerinden bazıları çok kriterli, karmaşık, çelişkili ve belirsiz olmalarıdır. Araştırmacı ve bilim adamları bu tür problemlerde çoğunlukla çok kriterli karar verme yöntemlerini (ÇKKV) kullanmaktadır [5-9] ve optimum sonuçlara ulaşılmaktadır. Çevresel uygulamalar kompleks ve belirsiz [10] olduğundan atık yönetimi problemlerinde de birçok araştırmacı [11-20] ÇKKV yöntemlerini kullanmakta veya kullanılmasını önermektedir.

Bu çalışmanın amacı çevresel uygulama olan ve yaygın şekilde de atık/atık suların arıtımı için tam ölçekli olarak kullanılan anaerobik çürütmenin mezofilik mi yoksa termofilik mi olarak işletilmesi daha öncelikli olduğunu fayda, maliyet ve risk açısından belirlemektir. Literatür çalışması sonucunda katı atık bertarafı için alternatiflerden biri olarak ele alındığı fakat mezofilik/termofilik işletme açısından ele alınmadığı gözlenmiştir. Bu sebeple de literatür ve üç uzmanın bilgisine dayanarak mezofilik ve termofilik sıcaklıklarda işletilen anaerobik çürütmenin fayda, maliyet ve risk ana kriterleri açısından önem sıraları belirlenmiştir. Bu yöntemlerden en etkin yöntemin seçilmesinde ele alınacak fayda, maliyet ve risk ana kriterleri için alt kriterler de belirlenerek, AHP ve TOPSİS yöntemleri ile karar verilmeye çalışılmıştır. 


\section{Materyal ve Metot}

\section{1. ÇKKV Teknikleri}

Bu çalışmada mezofilik ve termofilik anaerobik çürütmenin fayda, maliyet ve risk kriterleri açısından karşlaştırmaları AHP ve TOPSİS yöntemleri ile önceliklendirilmiştir. AHP ve TOPSİS çözümleri Excel programı ile gerçekleştirilmiştir.

AHP (Analytic Hierarchy Process) yöntemi Thomas L. Saaty tarafindan 1980 y1linda geliştirilmiştir [21]. AHP, çok kriterli problemleri hiyerarşik olarak yapılandırarak görselleştirmektedir. Nicel ve nitel kriterlerin kullanıldığı bu yöntemde karar vericinin her bir kriterin, alt kriterin ve alternatiflerin göreceli önemleri belirlenmektedir ve uygun alternatif seçilebilmektedir/sıralanabilmektedir. Tutarlılık oranı(CR) 0,1 'den küçük olması karar vericinin yaptığ1 karşılaştırmaların tutarlı olduğunu gösterir.

AHP'nin adımları aşağıda verilmiştir.

Adım 1: Amacın, alternatiflerin ve kriterlerin belirlenmesi

Adım 2: İkili karşılaştırma matrisi ve çözümü

Adım 3: Normalleştirme ve göreli önem ağırlıkları

Adım 4: Öncelik vektörünün elde edilmesi

Adım 5: Tutarlılık oranının (CR) hesaplanması

Adım 6: Nihai sıranın/seçmenin belirlenmesi

TOPSISS (Technique for Order Prefence by Similarity to Ideal Solution) yöntemi Hwang ve Yoon'un çalışması [22] referans alınarak Chen ve Hwang [23] tarafindan 1992'de geliştirilmiştir. Bu teknik ile karar verilirken bir alternatifin pozitif ideal çözüme yakın olması ve negatif ideal çözüme de uzak olması beklenir. Böylece, fayda kriterleri maksimize edilirken maliyet kriterleri minimize edilmektedir [24].

TOPSİS'in adımları aşağıda verilmiştir:

Adım 1: Alternatiflerin ve değerlendirme kriterlerin belirlenmesi

Adım 2: Kriterler ve alternatifler ile karar matrisinin oluşturulması

Adım 3: Normalleştirilmiş karar matrisinin oluşturulması

Adım 4: Ağırlıklı normalleştirilmiş karar matrisinin oluşturulması

Adım 5: İdeal (A*) ve negatif ideal (A) çözümlerin oluşturulması

Adım 6: İdeal ve negatif ideal noktalara uzaklıkların belirlenmesi

Adım 7: İdeal çözüme göreli yakınlığın hesaplanması ve karar verilmesi

\subsection{Kriterler}

Çalışma çok kriterli karar verme süreci olduğundan anaerobik çürütmenin en etkinine karar vermek için uzmanlarla beyin firtınası seansları yapılmıştır. Uzmanlar yazar haricinde üç kişi ve konusunda uzman kişilerden oluşmuştur. Mezofilik (M-AÇ) ve termofilik (T-AÇ) anaerobik çürütme alternatiflerinden en uygunun seçimi için fayda, maliyet ve risk kriterleri, her bir kriter içinde farklı sayıda alt kriterlere karar verilmiştir. Fayda kriteri için 4, maliyet kriteri için 2 ve risk kriteri için 3 tane alt kriter belirlenmiştir. Bu kriterler Tablo 1'de verilmiştir.

Tablo 1. Ana ve alt kriterler

\begin{tabular}{llll}
\hline Ana Kriterler & Fayda & Maliyet & Risk \\
\hline Alt Kriterler & KOİ Giderimi & Yatırım & Emisyon \\
& $\mathrm{CH}_{4}$ Üretimi & İşletme & Patojen Mikroorganizma \\
& Reaksiyon Süresi & & Sıvı Ürün Kalitesi \\
& Stabilite & & \\
\hline
\end{tabular}




\subsection{Mezofilik ve Termofilik Anaerobik Çürütmenin Karşılaştırılması}

Anaerobik çürütme hem atık/atık suların stabilizasyonunu ve hacim/kütle azaltmasını (\%30-50) [25] hem de biyometan eldesi sağlayan bir yöntemdir. Sera gazı emisyonunun azaltılmasına yardımcı olmasının yanısıra düzenli depolama yükünü de azaltmaktadır $[3,26]$. Ayrıca bu yöntem ile katı/sıv1 gübre üretilebilmektedir. Tablo 2'de mezofilik ve termofilik anaerobik çürütme karşıllaştırılmıştır.

Tablo 2. Mezofilik ve termofilik anaerobik çürütmenin avantaj-dezavantajları [26; 27-31]

\begin{tabular}{|c|c|c|}
\hline & Mezofilik & Termofilik \\
\hline \multirow[t]{11}{*}{ Avantajlar } & Daha iyi proses kararlılığ & Yüksek organik yüklemelerde çalışabilme \\
\hline & Daha az işletme maliyeti & Atık su soğuk olsa bile bu etkiyi elimine edebilme \\
\hline & $\mathrm{N}, \mathrm{P}$ ve $\mathrm{pH}$ yaklaşı ayn & KOİ ve metan verimi daha yüksek \\
\hline & & Daha hızlı ayrışma \\
\hline & & Daha küçük reaktör hacmi \\
\hline & & Çıkış AKM konsantrasyonu yaklaşık 2 kat az \\
\hline & & $\mathrm{N}, \mathrm{P}$ ve $\mathrm{pH}$ yaklaşık aynı \\
\hline & & Patojen ve E.Coli bakteri gideriminde yeterli \\
\hline & & Kısa sürede ayrışma sonucu daha az $\mathrm{H}_{2} \mathrm{~S}$, daha az koku \\
\hline & & Daha az köpüklenme \\
\hline & & Çürütülmüş ürünün daha iyi susuzlaştırılabilirliği \\
\hline \multirow[t]{5}{*}{ Dezavantajlar } & Daha düşük KOİ ve metan verimi & Kararsızlığa gitme eğilimi yüksek \\
\hline & Asetik asit daha baskın & UYA türleri hemen hemen ayn1 \\
\hline & $\begin{array}{l}\text { Çıkış AKM konsantrasyonu daha } \\
\text { fazla }\end{array}$ & $\mathrm{NH}_{3}$ miktarı daha yüksek \\
\hline & $\begin{array}{l}\text { E.Coli bakteri gideriminde düşük } \\
\text { verim }\end{array}$ & Sicaklık değişimine daha fazla duyarlı $( \pm 0.5)$ \\
\hline & Toksik bileşiklere duyarlılık & Toksik bileşiklere duyarlılık \\
\hline
\end{tabular}
yağ asidi, $\mathrm{NH}_{3}$ : Amonyak)

Mezofilik sıcaklıklarda anaerobik çürütme, termofilik sıcaklıklara kıyasla daha yaygın kullanıma sahiptir. Mezofilik sıcaklıklarda uçucu katı maddelerin ayrışması 30-40 günde gerçekleşmesine rağmen bu sıcaklık aralığı birçok sayıda metan oluşturan mikroorganizmalar için optimum olabilmektedir. Ayrıca, mezofilik sıcaklıklar düşük enerji kullanımı gerektirir. Termofilik sıcaklıklar hem bulaşıcı hayvan virüslerin hem de bakteriyofajların daha yüksek giderimini sağlamaktadır [32]. Termofilik sıcaklıklarda çürütme daha fazla avantajlara sahip olmasına rağmen (Tablo 2) sınırlı kullanılmasının başlıca sebepleri kötü proses stabilitesi, kötü üst faz kalitesi [33] ve işletme maliyetinin yüksekliğidir. Termofilik çürütmenin daha az kararlı olması, daha az mikrobiyal topluluk içermesi, propiyat asidinin kararlılığ ve artan ara ürün toksikliğidir [34]. Bu sebeple de giriş substratının azot benzeri bileşenler (üre, protein, vb.), asit, mikrobiyal içeriği vb. özellikleri performansı ve stabiliteyi etkileyen en önemli parametrelerdir [34]. Hammaddenin yüksek azot (N) içerikli olmas1 özellikle de termofilik şartlarda ayrışma sonucu yüksek amonyağa ve yüksek amonyak ise uçucu yă asidi (UYA) birikimine neden olarak sistemi olumsuz etkilemektedir. Yüksek $\mathrm{NH}_{3}, \mathrm{pH}$ artışına da neden olmaktadır [31]. Qi vd. [35] sığır gübresinin termofilik ve mezofilik sıcaklıklarda çürütülmesi sonucu oluşan ürünlerin çevresel risklerini indikatör bakterileri ve ağır metalleri analiz ederek belirlemişlerdir. Çalışma sonucunda indikatör bakterilerde azalma ve ağır metallerin düşük içeriği tespit edilmiştir. Termofilik üründe azotun daha yüksek olduğu mezofilik üründe ise Bacillus ve Pseudomonas'ın miktarı daha yüksek ölçülmüştür. Diğer nütrientlerin ise benzer içeriğe sahip olduğu ifade edilmiştir.

\section{Bulgular ve Tartışma}

\subsection{AHP Verileri}

Mezofilik ve termofilik anaerobik çürütmenin fayda, maliyet ve risk açısından önceliklendirilmesi için önce AHP analizi gerçekleştirilmiştir. AHP analizinde de her bir ana kriter ele alınan alt kriterler açısından lokal değerlendirilmiştir ve elde edilen sonuçlar Şekil 2'de verilmiştir. 


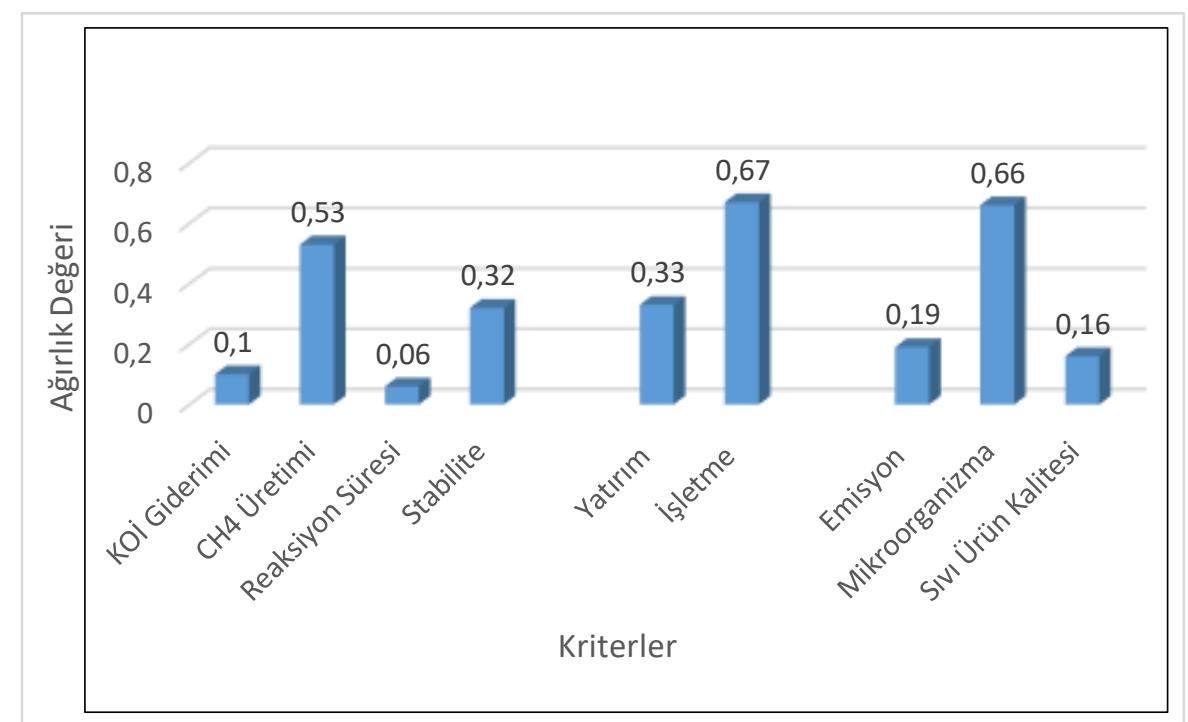

Şekil 2. Ana kriterlerin lokal değerlendirilmesi

Lokal değerlendirme sonuçlarından, fayda ana kriterinden $\mathrm{CH}_{4}$ üretimi $(0,53)$; maliyet ana kriterinden işletme maliyeti $(0,67)$ ve risk ana kriterinden ise mikroorganizma $(0,66)$ en yüksek ağırlık değerlerine sahip olduğu gözlenmiştir. Metan üretiminin öncelikli olması işletme maliyetini de azaltacağı için öncelikli olarak değerlendirilmiş olabilir. Stabilite alt kriteri de yine gaz verimini etkileyen bir parametre olduğu için metan üretiminden sonra en yüksek ağırlığa sahip kriter olarak belirlenmiştir. En düşük ağırlık değerine sahip alt kriter ise reaksiyon süresi olup KOİ giderimine yakın bir ağırlık değerine sahiptir. Reaksiyon süresinin uzunluğu (verimin iyi olması şartı ile) işletme maliyetini artırmaktadır. Bu açıdan reaksiyon süresinin bir arıtım yöntemi seçiminde uzun olması istenmez fakat ele alınan diğer kriterler (özellikle de $\mathrm{CH}_{4}$ üretimi ve stabilite) daha önemli kriterler olduğu uzmanlar tarafından düşünülmüştür.

Uzmanların tecrübesi ve literatür bilgisine dayanarak karar verilen alt kriterlerin genel değerlendirilmesinde elde edilen sonuçlar Şekil 3'te verilmiştir.

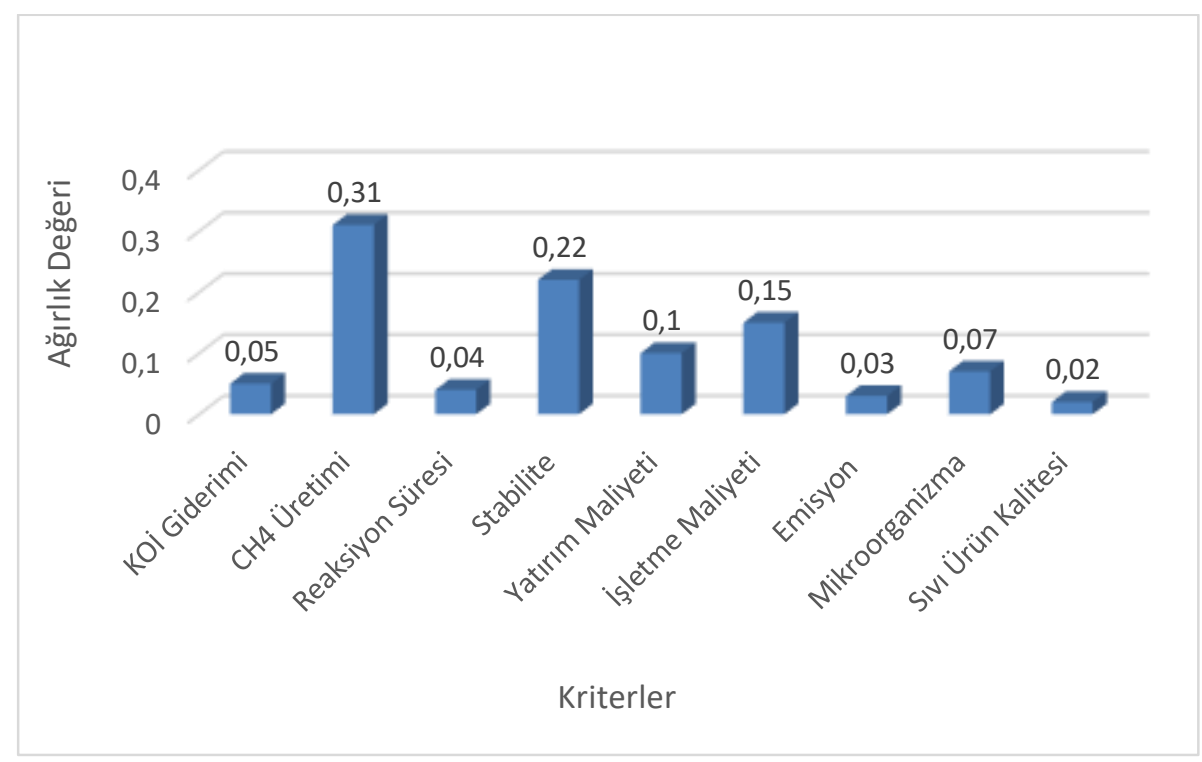

Şekil 3. Alt kriterlerin genel değerlendirilmesi

Şekil 3'teki sonuçlar incelendiğinde 9 alt kriterden en yüksek ağırlığa sahip olan alt kriterin $\mathrm{CH}_{4}$ üretimi olduğu görülmektedir. Diğer yüksek önceliğe sahip olan kriterler ise stabilite ve işletme maliyetidir. En düşük ağırlığa sahip alt kriter ise sıvı ürün kalitesidir. Aslında KOİ giderimi, reaksiyon süresi, emisyon ve sıvı ürün kalitesi alt kriterleri birbirlerine yakın ağırlık değerlerine sahiptir. 


\subsection{TOPSİS Verileri}

AHP yöntemi ile elde edilen ağırlık değerleri kullanılarak TOPSíS analizi gerçekleştirilmiştir. TOPSİS analizi için literatür taraması sonucunda Tablo 3 'teki veriler belirlenmiştir. Bu verilerin belirlenmesinde anaerobik çürütme ile ilgili gerçekleştirilen uygulamalı çalışmalardan bazıları (KOİ giderimi, $\mathrm{CH}_{4}$ üretimi, reaksiyon süresi, maliyet, mikroorganizma, sıvı ürün kalitesi) alınırken bazıları da (stabilite ve emisyon) literatürdeki çalışmalardan yorumlanarak tahmini olarak belirlenmiştir. Maliyet verileri 94 sığır yani yaklaşık $941 \mathrm{~kg} /$ gün gübrenin arıtımı için $94 \mathrm{~m}^{3}$ hacme sahip reaktörün yatırım ve işletme maliyeti dikkate alınmıştır. Bu veriler mezofilik sıcaklığa göre hesaplanmıştır [36]. Termofilik şartlarda kısa bekletme süresi yani daha küçük reaktör hacmi ve $45-55^{\circ} \mathrm{C}$ sıcaklıkta işletme yüksek elektrik tüketimi demektir. Bu bilgilere dayanarakta termofilik şartlarda işletme ve yatırım maliyeti tahminen 25000 TL (mezofilik şartlardakinin \%32 fazlası) ve 55000 TL (mezofilik şartlardakinin \%10 fazlası) olarak ele alınmıştır.

Tablo 3. AHP bazlı TOPSIS analizi için kullanılan veriler [27, 29, 37]

\begin{tabular}{lllll}
\hline Kriterler & Birim & M-AÇ & T-AÇ & Karar \\
\hline Fayda & & & & \\
\hline KOİ Giderimi & $\%$ & $75-85$ & $85-95$ & Maksimum \\
$\mathrm{CH}_{4}$ Üretimi & Kat & 1 & $1,5-2$ & Maksimum \\
Reaksiyon Süresi & Gün & $30-40$ & $15-20$ & Minimum \\
Stabilite & $1-10$ arası değer & 7 & 3 & Maksimum \\
\hline Maliyet & & & & \\
\hline Yatırım Maliyeti & TL & 50000 & 55000 & Minimum \\
İşletme Maliyeti & TL & 19000 & 25000 & Minimum \\
\hline Risk & & & & \\
\hline Emisyon & $\%$ & 30 & 20 & Minimum \\
Mikroorganizma & CFU/kg & 1000 & 10 & Minimum \\
Sivı Ürün Kalitesi & $\%$ & 65 & 75 & Maksimum \\
\hline
\end{tabular}

Her bir kriter açısından alternatifler değerlendirildiğinde ise fayda kriteri için T-AÇ, maliyet kriteri için M-AÇ ve risk kriteri için T-AÇ'ye karar verilmiştir. Tüm kriterler beraber ele alındığında ise ideal uzaklık değerleri M-AÇ ve T-AÇ için sırasıyla 0,29 ve 0,71 olarak belirlenmiştir. Sonuç olarak fayda, maliyet ve risk açısından en iyi yöntemin termofilik anaerobik çürütme olduğu söylenebilir.

Katı atık yönetim sistemlerinin (KAYS) seçimi ile ilgili bazı ÇKKV çalışmaları gerçekleştirilmiştir [17; 38-40]. Mir vd. [17] KAYS seçimi için anaerobik çürütme, düzenli depolama, RDF, kompostlaştırma ve geri dönüşüm alternatifleri çeşitli kriterlere göre TOPSİS ve VIKOR yöntemleri ile önceliklendirilmiştir. Sonuçta, anaerobik çürütme $\% 40,4$ ile geri dönüşüm $(\% 36,4)$, düzenli depolama $(\% 18,1)$, RDF $(\% 3,1)$ ve kompostlaştırma $(\% 2)$ alternatiflerine kıyasla daha öncelikli olarak belirlenmiştir. Pires vd. [38] Portekiz Setubal Yarımadası'ndaki KAYS seçimi için AHP ve TOPSİS ile değerlendirilmiştir. AHP ile ağırlıklandırmalar hesaplanmıştır ve TOPSİS ile sıralama yapılmıştır. Antonopoulos vd. [40] katı atık arıtım alternatifleri (mekanik biyolojik aerobik arıtma, mekanik biyolojik anaerobik arıtma ve enerji kazanımlı yakma) AHP ile önceliklendirilmiştir. Enerji kazanımlı yakma yüksek miktarda üretilen enerji nedeniyle en iyi performansı sağladığı ifade edilmiştir. Martowibowo ve Riyanto [39] Bandung şehrinde katı atık arıtım alternatiflerinin (kompostlaştırma, gazlaştırma, düzenli depolama, anaerobik çürütme, yakma ve açık depolama) seçiminde AHP, ELECTRE II, PROMETHEE II ve TOPSIS kullanılmıştır. Bu alternatiflerden kompostlaştırma en öncelikli olarak belirlenmiştir.

Literatür çalışmaları değerlendirildiğinde arıtım yöntemi alternatiflerini sıralarken veya en önceliklisini sıralarken birçok parametre kararı etkilemektedir. Ele alınan alternatifler, kriterler, anketörler (karar matrisini oluşturan kişiler) büyük etkiye sahiptir. Ayrıca hesaplamalarda kullanılan çok kriterli karar verme yöntemlerinin seçimi bile kararın farklı olmasına neden olabilmektedir. 
Yukarıda bahsedilen çalışmalardan da görüldüğü gibi ele alınan alternatiflerin bazıları ortak olsa bile öncelikli olarak farklı alternatif seçilmiş olabilir.

Bu çalışmada anaerobik çürütme mezofilik ve termofilik şartlara göre AHP ve TOPSİS ÇKKV teknikleri ile değerlendirilmiştir ve termofilik şart öncelikli olarak belirlenmiştir. Farklı alternatifler ve farklı ÇKKV teknikleri ile hesaplamalar yapılırsa aynı/farklı sonuçlar elde edilebilir. Termofilik anaerobik çürütmenin daha öncelikli belirlenmesinde en önemli etkenler sınırlı alternatif olması ve dikkate alınan kriterler olduğu söylenebilir.

\section{Sonuç ve Öneriler}

Gelişen sanayi ve teknoloji, ve artan insan ve hayvan nüfusu ile hem atık/atık sular oluşacaktır hem de her geçen gün enerji ihtiyacı artacaktır. İnsanoğlu var oldukça oluşan atık/atık suların doğaya en az zarar verecek şekilde uygun arıtma ve bertaraf yöntemleri ile yönetilmesi gerekmektedir. Atıkların yönetimi için yöntem seçilirken de sürdürülebilirliğin göze alınması büyük önem arzetmektedir. Bu sebeple de bu çalışmada sürdürülebilir arıtım yöntemi olan ve yaygın bir şekilde de tam ölçekli olarak işletilen anaerobik çürütmenin mezofilik ve termofilik sıcaklıklarda işletiminin fayda, maliyet ve risk açısından farklı alt kriterler de ele alınarak önceliklendirilmesi çok kriterli karar verme yöntemlerinden AHP ve TOPSIS ile yapılmıştır. Çalışma sonucunda her bir kriter ayrı ayrı olarak değerlendirildiğinde fayda kriteri için T-AÇ, maliyet kriteri için M-AÇ ve risk kriteri için T-AÇ öncelikli olarak belirlenirken tüm kriterler beraber ele alındığında ise T-AÇ öncelikli olarak hesaplanmıştır. Farklı alternatifler ve farklı ÇKKV teknikleri ile hesaplamalar yapılırsa aynı/farklı sonuçlar elde edilebilir. Termofilik anaerobik çürütmenin daha öncelikli belirlenmesinde en önemli etkenler sınırlı alternatiflerin olması ve dikkate alınan kriterlerdir. Gelecek çalışmalar için farklı kriter/alt kriterler ve farklı ÇKKV yöntemleri ile çalışmalar önerilebilir.

\section{Yazarların Katkısı}

Çalışmada tüm katkı yazara aittir.

\section{Çıkar Çatışması Beyanı}

Yazarlar arasında herhangi bir çıkar çatışması bulunmamaktadır.

\section{Araştırma ve Yayın Etiği Beyanı}

Yapılan çalışmada araştırma ve yayın etiğine uyulmuştur.

\section{Kaynaklar}

[1] Çetinkaya A.Y. 2018. Investigation of Biomethane Potential of Dairy Industry Wastewater. Journal of Polytechnic, 21 (2): 457-460.

[2] Çakır F.Y., Stenstrom M.K. 2005. Greenhouse Gas Production: A Comparison Between Aerobic and Anaerobic Wastewater Treatment Technology. Water Research, 39 (17): 4197-4203.

[3] Vindis P., Mursec B., Janzekovic M., Cus F. 2009. The Impact of Mesophilic and Thermophilic Anaerobic Digestion on Biogas Production. Journal of Achievements in Materials and Manufacturing Engineering, 36 (2): 192-198.

[4] Cavinato C., Fatone F., Bolzonella D., Pavan P. 2010. Thermophilic Anaerobic Co-Digestion of Cattle Manure With Agro-Wastes and Energy Crops: Comparison of Pilot and Full Scale Experiences. Bioresource Technology, 101 (2): 545-550.

[5] Turskis Z., Zavadskas E.K., Antucheviciene J., Kosareva N. 2015. A Hybrid Model Based on Fuzzy AHP and Fuzzy WASPAS For Construction Site Selection, International Journal of Computers Communications \& Control, 10 (6): 113-128.

[6] Yapici Pehlivan N., Şahin A., Zavadskas E., Turskis Z. 2018. A Comparative Study of Integrated FMCDM Methods For Evaluation of Organizational Strategy Development. Journal of Business Economics and Management, 19 (2): 360-381. 
[7] Toklu M.C., Uygun Ö. 2018. Location Selection For Wind Plant Using AHP and Axiomatic Design in Fuzzy Environment. Periodicals of Engineering and Natural Sciences (PEN), 6 (2): 120-128.

[8] Zavadskas E.K., Kaklauskas A., Kalibatas D., Turskis Z., Krutinis M., Bartkienė L. 2018. Applying the TOPSIS-F Method to Assess Air Pollution in Vilnius. Environmental Engineering \& Management Journal (EEMJ), 17 (9).

[9] Abdullah L., Zulkifli N., Liao H., Herrera-Viedma E., Al-Barakati A. 2019. An Interval-Valued Intuitionistic Fuzzy DEMATEL Method Combined with Choquet Integral For Sustainable Solid Waste Management. Engineering Applications of Artificial Intelligence, 82: 207-215.

[10] Tseng M.L. 2011. Using a Hybrid MCDM Model To Evaluate Firm Environmental Knowledge Management in Uncertainty. Applied Soft Computing, 11 (1): 1340-1352.

[11] Vego G., Kučar-Dragičević S., Koprivanac N. 2008. Application of Multi-Criteria DecisionMaking on Strategic Municipal Solid Waste Management in Dalmatia. Croatia, Waste Management, 28 (11): 2192-2201.

[12] Tseng M.L. 2009. Application of ANP and DEMATEL to Evaluate The Decision-Making of Municipal Solid Waste Management in Metro Manila. Environmental Monitoring and Assessment, 156 (181): 1-4.

[13] Dursun M., Karsak E.E. Karadayi M.A. 2011. A Fuzzy MCDM Approach For Health-Care Waste Management. World Academy of Science, Engineering and Technology International Journal of Industrial and Manufacturing Engineering, 5 (1).

[14] Büyüközkan G., Çifçi G. 2012. A Novel Hybrid MCDM Approach Based on Fuzzy DEMATEL, Fuzzy ANP and Fuzzy TOPSIS to Evaluate Green Suppliers. Expert Systems with Applications, 39 (3): 3000-3011.

[15] Nixon J.D., Dey P.K., Ghosh S.K., Davies P.A. 2013. Evaluation of Options For Energy Recovery From Municipal Solid Waste in India Using the Hierarchical Analytical Network Process. Energy, 59: 215-223.

[16] Liu H.C., You J.X., Fan X.J., Chen Y.Z. 2014. Site Selection in Waste Management By The VIKOR Method Using Linguistic Assessment. Applied Soft Computing, 21: 453-461.

[17] Mir M.A., Ghazvinei P.T., Sulaiman,N.M.N., Basri N.E.A., Saheri S., Mahmood N.Z., Aghamohammadi N. 2016. Application of TOPSIS and VIKOR Improved Versions in A Multi Criteria Decision Analysis to Develop An Optimized Municipal Solid Waste Management Model. Journal of Environmental Management, 166: 109-115.

[18] Arıkan E., Şimşit-Kalender Z.T. Vayvay Ö. 2017. Solid Waste Disposal Methodology Selection Using Multi-Criteria Decision Making Methods and An Application in Turkey. Journal of Cleaner Production, 142: 403-412.

[19] Goulart Coelho L.M., Lange L.C., Coelho H.M. 2017. Multi-Criteria Decision Making To Support Waste Management: A Critical Review of Current Practices and Methods. Waste Management \& Research, 35 (1): 3-28.

[20] Coban A., Ertis I.F., Cavdaroglu N.A. 2018. Municipal Solid Waste Management via MultiCriteria Decision Making Methods: A Case Study in Istanbul, Turkey. Journal of Cleaner Production, 180: 159-167.

[21] Saaty T.L. 1980. The Analytic Hierarchy Process. McGraw-Hill, New York, USA.

[22] Hwang C.L., Yoon K. 1981. Multiple Attribute Decision Making: Methods and Application. Springer, Berlin.

[23] Cheng S., Hwang C. 1992. Fuzzy Multiple Attribute Decision Making: Methods and Applications. Lecture Notes in Economics and Mathematical Systems. Springer.

[24] Alp S., Engin T. 2011. Analysis and Evaluation of The Relation Between The Reasons and Consequences of The Traffic Accidents By Using TOPSIS and AHP Methods. İstanbul Ticaret Üniversitesi Fen Bilimleri Dergisi, 10 (19): 65-87.

[25] Nges I.A., Liu J. 2010. Effects of Solid Retention Time on Anaerobic Digestion of DewateredSewage Sludge in Mesophilic and Thermophilic Conditions. Renewable Energy, 35 (10): 22002206.

[26] Aich A., Ghosh S.K. 2016. Application of SWOT Analysis for the Selection of Technology for Processing and Disposal of MSW. Procedia Environmental Sciences, 35: 209-228. 
[27] Coşkun T., Manav N., Debik E., Binici M.S., Tosun C., Mehmetli E., Baban A. 2011. Anaerobic Digestion of Cattle Manure. Journal of Engineering and Natural Sciences, 3: 1-9.

[28] Kardos L., Juhasz A., Palko G., Olah J., Barkacs K., Zaray G. 2011. Comparing of Mesophilic and Thermophilic Anaerobic Fermented Sewage Sludge Based on Chemical and Biochemical Tests. Applied Ecology and Environmental Research, 9 (3): 293-302.

[29] Şentürk E. 2010. Investigation on The Treatability and Modelling of Potato-Processing Wastewaters in A Completely Mixed Anaerobic Contact Reactor Under Mesophilic and Thermophilic Conditions. PhD Thesis, Gebze Technical University, Environmental Engineering, Kocaeli.

[30] Öztürk M. 2017. Hayvan Gübresinden Biyogaz Üretimi. Çevre ve Şehircilik Bakanlığı, Ankara, 1-71. http://www.cevresehirkutuphanesi.com/assets/files/slider_pdf/UWDntXjXQmfS.pdf. (Erişim Tarihi: 05.09.2019).

[31] Bi S., Qiao W., Xiong L., Ricci M., Adani F., Dong R. 2019. Effects of Organic Loading Rate on Anaerobic Digestion of Chicken Manure Under Mesophilic and Thermophilic Conditions. Renewable Energy, 139: 242-250.

[32] Sassi H.P., Ikner L.A., Abd-Elmaksoud S., Gerba C.P., Pepper I.L. 2018. Comparative Survival of Viruses During Thermophilic and Mesophilic Anaerobic Digestion. The Science of the Total Environment, 615: 15-19.

[33] Kim M., Ahn Y.H., Speece R. 2002. Comparative Process Stability and Efficiency of Anaerobic Digestion; Mesophilic vs. Thermophilic. Water Research, 36 (17): 4369-4385.

[34] Labatut R.A., Angenent L.T., Scott N.R. 2014. Conventional Mesophilic vs. Thermophilic Anaerobic Digestion: A Trade-Off Between Performance and Stability? Water Research, 53: 249258.

[35] Qi G., Pan Z., Sugawa Y., Andriamanohiarisoamanana F.J., Yamashiro T., Iwasaki M., Kawamoto K., Ihara I., Umetsu K. 2018. Comparative Fertilizer Properties of Digestates From Mesophilic and Thermophilic Anaerobic Digestion of Dairy Manure: Focusing on Plant Growth Promoting Bacteria (PGPB) and Environmental Risk. Journal of Material Cycles and Waste Management, 20 (3): 1448-1457.

[36] Tufaner F., Avsar Y., 2019. Economic Analysis of Biogas Production From Small Scale Anaerobic Digestion Systems For Cattle Manure. Environmental Research and Technology, 2(1): 6-12.

[37] Yakut H.U. 2012. Investigation of The Effect of Mixer Speed on Biogas Production. MSc Thesis, Kocaeli University, Department of Machine Engineering, Kocaeli.

[38] Pires A., Chang N.B., Martinho G. 2011. An AHP-Based Fuzzy Interval TOPSIS Assessment For Sustainable Expansion of the Solid Waste Management System in Setúbal Peninsula, Portugal. Resources, Conservation and Recycling, 56 (1): 7-21.

[39] Martowibowo S.Y., Riyanto H. 2011. Suitable Multi Criteria Decision Analysis Tool For Selecting Municipal Solid Waste Treatment in The City of Bandung. Journal of KONES Powertrain and Transport, 18 (4).

[40] Antonopoulos I.S., Perkoulidis G., Logothetis D., Karkanias C. 2014. Ranking Municipal Solid Waste Treatment Alternatives Considering Sustainability Criteria Using The Analytical Hierarchical Process Tool. Resources, Conservation and Recycling, 86: 149-159. 